\title{
PENGARUH KONSENTRASI GIBERELIN DAN LAMA PERENDAMAN TERHADAP PERKECAMBAHAN BIJI SIRSAK (Anonna muricata L.)
}

\author{
Silvia Polhaupessy dan Hermalina Sinay \\ Program Studi Pendidikan Biologi \\ E-mail: silvi_polhaupessy@yahoo.com
}

\begin{abstract}
Background: The aim of this research was want to know the effect of GA concentration with soaking time towards seedling germination of soursop, and to know whichone of the treatment that can give a very highest quality and quantity of seedling germination of soursop.

Method: This research started from $2 \mathbf{9}^{\text {st }}$ Juny until $2 \mathbf{9}^{\text {st }}$ July 2011. Factorial pattern of completely randomized block design (RAL) were used in this research, which consist of two factors. First factor where concentration of GA with four level i.e. $A_{1}=5$ PPM, $A_{2}=10$ PPM, $A_{3}=15$ PPM, and $A_{4}=20$ PPM. While the second factor where soaking time which consist of three level i.e. $L_{1}=$ soaking for six hour, $L_{2}$ = soaking for twelve hours, $L_{3}=$ soaking for twenty-four hours. Each combination with three replicated. Data collected were analyzed used analysis of variance at the significant level of $\alpha 0,05$ and 0,01 .

Result: Percentage obtained at the $A_{3} L_{2}$ treatment i.e. $100 \%$, plant high $16,12 \mathrm{~cm}$, and root length $12,99 \mathrm{~cm}$. It can be concluding that $\mathrm{GA}$ and soaking time treatment, can affected the seedling germination of soursop.

Conclusion: Based on the results obtained it can be concluded that the use of GA concentration and different soaking time on seed soursop significant effect on percentage germination, high germination and seedling root length.
\end{abstract}

Keyword: GA, Soaking Time, Seedling, Germination, Anonna muricata L.

\begin{abstract}
Abstrak
Latar Belakang: Tujuan dari penelitian ini adalah ingin mengetahui pengaruh konsentrasi GA dengan waktu perendaman terhadap bibit perkecambahan sirsak, dan untuk mengetahui whichone dari pengobatan yang dapat memberikan kualitas yang sangat tinggi dan kuantitas bibit perkecambahan sirsak.

Metode: Penelitian dimulai dari Juni - Juli 2011. faktorial pola rancangan acak kelompok (RAL) yang digunakan dalam penelitian ini, yang terdiri dari dua faktor. Faktor pertama di mana konsentrasi GA dengan empat tingkat yaitu $\mathrm{A} 1=5 \mathrm{PPM}, \mathrm{A} 2=10 \mathrm{PPM}, \mathrm{A} 3=15 \mathrm{PPM}$, dan A4 = 20 PPM. Sedangkan faktor kedua di mana waktu perendaman yang terdiri dari tiga tingkat yaitu $\mathrm{L} 1=$ perendaman selama enam jam, L2 = perendaman selama dua belas jam, L3 = perendaman selama dua puluh empat jam. Setiap kombinasi dengan tiga direplikasi. Data analisis menggunakan varian pada tingkat signifikan $\alpha$ 0,05 dan 0,01 .

Hasil: Konsentrasi GA dan waktu perendaman yang berbeda mempengaruhi perkecambahan bibit sirsak terutama dengan persentase perkecambahan, tanaman hight dan akar panjang bibit. Persentase tertinggi perkecambahan diperoleh pada perlakuan A3L2 yaitu $100 \%$, tinggi tanaman $16,12 \mathrm{~cm}$, dan panjang akar 12,99 $\mathrm{cm}$. Hal ini dapat menyimpulkan bahwa GA dan pengobatan waktu perendaman, dapat mempengaruhi perkecambahan bibit sirsak.

Kesimpulan: Penggunaan konsentrasi GA dan waktu perendaman yang berbeda pada biji sirsak berpengaruh signifikan terhadap persentase perkecambahan, perkecambahan tinggi dan panjang akar.
\end{abstract}

Kata kunci: GA, Waktu Perendaman, Bibit, Perbenihan, Anonna muricata L. 


\section{PENDAHULUAN}

Proses pertumbuhan tanaman secara alami dimulai dengan perkecambahan biji, yang merupakan tahap munculnya radikula pada testa benih (Salisbury dan Ross, 1995). Namun demikian, salah satu faktor yang mempengaruhi ketidakberhasilan perbanyakan tanaman secara generatif melalui biji adalah rendahnya kemampuan biji untuk berkecambah (Anonim, 2007). Rendahnya kemampuan biji untuk berkecambah dapat disebabkan oleh beberapa faktor yaitu tingkat kemasakan benih, ukuran benih, dormansi, penghambat perkecambahan, air, temperatur, oksigen, dan cahaya (Sutopo 2002:25).

Sirsak (Anonna muricata L.) merupakan salah satu tanaman yang belum banyak diusahakan secara khusus, padahal komoditas ini memiliki prospek yang sangat baik. Menurut Radi (1997:16), perbanyakan tanaman sirsak dapat dilakukan secara generatif maupun vegetatif. Namun umumnya masyarakat petani memperbanyak sirsak secara generatif yaitu melalui biji karena sifatnya yang homozigot, sehingga hasil perbanyakan dengan biji kualitasnya tidak kalah dibandingkan dengan tanaman induk. Salah satu faktor yang menjadi hambatan dalam mengusahakan tanaman sirsak adalah kondisi bijinya yang tergolong dalam biji keras, sehingga untuk berkecambah sirsak memerlukan waktu yang cukup lama. Oleh sebab itu untuk meningkatkan kemampuan biji untuk berkecambah, dapat dilakukan perlakuan-perlakuan untuk memacu perkecambahan diantaranya perlakuan pemberian senyawa sintetik yang lazim disebut Zat Pengatur Tumbuh (ZPT). Salah satu hormon tumbuh yang dapat digunakan untuk memacu perkecambahan adalah giberelin.

Hedy (1996:25) mengemukakan bahwa giberelin (GA) merupakan salah satu zat pengatur tumbuh yang dapat menghilangkan dormansi pada kulit biji dan tunas sejumlah tanaman serta mempercepat perkecambahan. Banyak benih memiliki giberelin khususnya pada embrio. Setelah air diimbibisi, pembebasan giberelin dari embrio akan memberikan sinyal pada biji untuk mengakhiri dormansinya dan berkecambah (Campbell, dkk:2003). Respons positif GA terjadi dalam kisaran konsentrasi yang luas, berbeda dengan respons terhadap auksin yaitu hanya dalam konsentrasi yang sempit (Gardner, dkk 1991:223). Hal ini sesuai dengan pendapat Maryeni (2007) yang menyatakan bahwa semakin tinggi konsentrasi GA yang diberikan maka tinggi bibit kina semakin bertambah.

Asatutik dan Puji (2006) melaporkan bahwa pemberian konsentrasi giberelin dan lama perendaman pada biji jati (Tectona grandis L.) mampu memberikan pengaruh signifikan terhadap persentase perkecambahan biji jati sampai $60 \%$ yaitu dengan memberikan kombinasi giberelin 10 ppm dengan lama waktu perendaman 24 jam. Selain itu menurut Soedjono dan Suskandari (1997) pemberian konsentrasi GA 1000 ppm dan lama perendaman selama 72 jam mampu meningkatkan daya kecambah sampai $83,5 \%$ pada biji palem.

\section{MATERI DAN METODE}

Penelitian ini menggunakan tipe penelitian eksperimen guna melihat pengaruh konsentrasi giberelin dan lama perendaman terhadap perkecambahan biji sirsak. Penelitian ini dilaksanakan di Laboratorium Biologi Fakultas MIPA Unpatti. Penelitian ini dilaksanakan selama 1 (satu) bulan, daritanggal 29 Juni-29 Juli 2011.

Objek dalam penelitian ini adalah biji sirsak yang diambil dari daging buah yang dipetik dari pohon dan telah masak secara fisiologis, dimana sampel yang diambil secara purposive sampling sebanyak 195 biji untuk 12 kombinasi perlakuan dengan 3 ulangan. Alat dan bahan yang digunakan berupa Gelas Ukur, Gelas piala 1000 ml, Mistar, Alat Tulis Menulis, Neraca Analitik, Kamera, Pinset, Botol penyemprot, Tempat air suling, Polybag, tanah hitam, akuades, GA, biji sirsak dan kertas label.

Penelitian ini menggunakan Rancangan acak lengkap (RAL) pola faktorial dengan dua faktor yaitu konsentrasi GA yang terdiri dari 4 taraf dan lama perendaman yang terdiri dari 3 taraf, dengan setiap perlakuan dibuat 3 ulangan dan sebagai pembanding terhadap perlakuan digunakan kontrol : 
Faktor 1. Konsentrasi GA $(A)$

$A_{0}=$ Kontrol (Tanpa GA)

$\mathrm{A}_{1}=\mathrm{GA}$ Konsentrasi $5 \mathrm{ppm}$

$\mathrm{A}_{2}=\mathrm{GA}$ Konsentrasi $10 \mathrm{ppm}$

$\mathrm{A}_{3}=\mathrm{GA}$ Konsentrasi $15 \mathrm{ppm}$
$\mathrm{A}_{4}=\mathrm{GA}$ Konsentrasi $20 \mathrm{ppm}$

Faktor 2. Lama Perendaman (L)

$\mathrm{L}_{1}=$ Perendaman6 Jam

$\mathrm{L}_{2}=$ Perendaman $12 \mathrm{Jam}$

$\mathrm{L}_{3}=$ Perendaman $24 \mathrm{Jam}$

Tabel 1. Kombinasi Perlakuan Konsentrasi dan Lama Perendamannya

\begin{tabular}{cccc}
\hline \multirow{2}{*}{ Konsentrasi GA } & \multicolumn{3}{c}{ Lama Perendaman } \\
\cline { 2 - 4 } & $\mathbf{L}_{\mathbf{1}}$ & $\mathbf{L}_{2}$ & $\mathrm{~L}_{3}$ \\
\hline$A_{1}$ & $\mathrm{~A}_{1} L_{1}$ & $\mathrm{~A}_{1} L_{2}$ & $\mathrm{~A}_{1} L_{3}$ \\
$A_{2}$ & $A_{2} L_{1}$ & $A_{2} L_{2}$ & $A_{2} L_{3}$ \\
$A_{3}$ & $A_{3} L_{1}$ & $A_{3} L_{2}$ & $A_{3} L_{3}$ \\
$A_{4}$ & $A_{4} L_{1}$ & $A_{4} L_{2}$ & $A_{4} L_{3}$ \\
\hline
\end{tabular}

Prosedur kerja dalam penelitian ini yaitu tahap persiapan alat dan bahan, persiapan benih, penyiapan larutan GA, perendeman benih, pemindahan benih pada polybag dan pengamatan yang dilakukan selama 1 bulan. Peneliti melakukan pengamatan langsung terhadap perkecambahan biji sirsak setelah direndam dalam larutan GA sesuai konsentrasi dan waktu yang sudah ditentukan. Untuk mencari nilai persentase perkecambahan digunakan rumus: $\%$ Perkecambahan $=\frac{\text { Benih Yang Berkecambah }}{\text { Contoh Benih Yang Diuji }} \times 100 \%$ (Sutopo, 2002)

Selanjutnya data yang diperoleh dianalisis menggunakan analisis keragaman atau analisis variansi (Analisis of Variance), dengan langkah perhitungan mengikuti rumus dari Gomez dan Gomez 1995. Apabila nilai $F$ hitung > nilai $F$ tabel, maka dilanjutkan dengan uji beda nyata terkecil/ LSD (Least Significan Difference).

\section{HASIL DAN PEMBAHASAN}

Berdasarkan hasil analisis variansi persentase perkecambahan biji sirsak yang diperlihatkan pada Tabel 1.di bawah ini terlihat bahwa perlakuan kombinasi GA dan lama perendaman berpengaruh sangat nyata pada taraf uji 0,05 dan 0,01 ( $F_{\text {hitung }}>$ $\left.F_{\text {tabel }}\right)$ terhadap persentase perkecambahan.

Tabel 2. Analisis Variansi Persentase Perkecambahan Biji Sirsak (Anonna muricata L.).

\begin{tabular}{lcccccc}
\hline \multirow{2}{*}{ Sumber Keragaman } & \multirow{2}{*}{ DB } & \multirow{2}{*}{ JK } & \multirow{2}{*}{ KT } & \multirow{2}{*}{ F Hitung $_{n}$} & \multicolumn{2}{c}{ F $_{\text {Tabel }}$} \\
\hline Perlakuan & 12 & 9066,67 & 755,56 & $24,5^{*}$ & 2,15 & 2,01 \\
Konsentrasi GA (A) & 3 & 1022,23 & 340,74 & & & \\
Lama Perendaman (L) & 2 & 1100 & 550 & & & \\
Interaksi AL & 6 & 6944,44 & 1157,41 & & & \\
Galat & 26 & 800 & 30,77 & & & \\
Total & 38 & 9866,67 & & & & \\
\hline
\end{tabular}

$\mathrm{KK}=0,46 \%$

Ket $=$ Berpengaruh sangat nyata 
Berdasarkan hasil analisis variansi tinggi kecambah biji sirsak pada Tabel 2.di bawah ini terlihat bahwa perlakuan kombinasi GA dan lama perendaman berpengaruh sangat nyata pada taraf uji 0,05 dan 0,01 ( $\left.F_{\text {hitung }}>F_{\text {tabel }}\right)$ terhadap tinggi kecambah.

Tabel 2. Analisis Variansi Tinggi Kecambah Biji Sirsak (Anonna muricata L.).

\begin{tabular}{lcccccc}
\hline \multirow{2}{*}{ Sumber Keragaman } & \multirow{2}{*}{ DB } & \multirow{2}{*}{ JK } & \multirow{2}{*}{ KT } & \multirow{2}{*}{ F $_{\text {Hitung }}$} & \multicolumn{2}{c}{ F $_{\text {Tabel }}$} \\
\cline { 6 - 7 } & & & & 0,05 & 0,01 \\
\hline Perlakuan & 12 & 303,64 & 25,3 & $20,48^{* *}$ & 2,15 & 2,96 \\
Konsentrasi GA (A) & 3 & 190,72 & 63,57 & & & \\
Lama Perendaman (L) & 2 & 110,32 & 55,16 & & & \\
Interaksi AL & 6 & 2,6 & 0,43 & & & \\
Galat & 26 & 5,56 & 0,21 & & & \\
Total & 38 & 309,2 & & & & \\
\hline
\end{tabular}

$\mathrm{KK}=0,29 \%$

Ket $=$ Berpengaruh sangat nyata

Berdasarkan hasil analisis variansi panjang akar kecambah biji sirsak pada tabel 3.di bawah ini terlihat bahwa perlakuan kombinasi GA dan lama perendaman berpengaruh sangat nyata pada taraf 0,05 dan 0,01 ( $\left.F_{\text {hitung }}>F_{\text {tabel }}\right)$ terhadap panjang akar kecambah.

Tabel 3. Analisis Variansi Panjang Akar Kecambah Biji Sirsak(Anonna muricata L.).

\begin{tabular}{lcccccc}
\hline \multirow{2}{*}{ Sumber Keragaman } & \multirow{2}{*}{ DB } & \multirow{2}{*}{ JK } & KT & \multirow{2}{*}{ F $_{\text {Hitung }}$} & \multicolumn{2}{c}{$\mathbf{F}_{\text {Tabel }}$} \\
\cline { 6 - 7 } & & & & 0,05 & 0,01 \\
\hline Perlakuan & 12 & 182,93 & 15,24 & $60,96^{* *}$ & 2,15 & 2,96 \\
Konsentrasi GA (A) & 3 & 112,02 & 37,34 & & & \\
Lama Perendaman (L) & 2 & 69,17 & 34,59 & & & \\
Interaksi AL & 6 & 1,74 & 0,29 & & & \\
Galat & 26 & 6.57 & & & & \\
Total & 38 & 189,5 & & & & \\
\hline
\end{tabular}

$\mathrm{KK}=0,38 \%$

Ket: Berpengaruh sangat nyata

Hasil pengamatan perlakuan kombinasi GA dan lama perendaman terhadap persentase perkecambahan biji sirsak ( $A$. muricata L.) yang dilaksanakan di laboratorium menunjukkan bahwa nilai tertinggi diperoleh pada biji-biji sirsak yang diberikan perlakuan kombinasi GA dan lama perendaman.Hal ini disebabkan karena penyerapan air oleh biji-biji sirsak tersebut berlangsung cepat juga daya rangsang dari zat tumbuh giberelin mampu mendorong proses penyerapan air dari biji-biji sirsak sehingga pertumbuhan dari biji sirsak juga berlangsung dengan cepat dan mampu memberikan respons fisiologis yang baik dengan menghasilkan kecambah-kecambah yang normal.
Dari data pengamatan terhadap persentase perkecambahan diperoleh bahwa pada perlakuan kombinasi $G A$ dan lama perendaman $A_{1} L_{1}, A_{1} L_{2}, A_{2} L_{1}, A_{2} L_{2}, A_{2} L_{3}$, $A_{3} L_{1}, A_{3} L_{2}, A_{3} L_{3}, A_{4} L_{1}, A_{4} L_{2}$, memiliki nilai persentase perkecambahan lebih tinggi, tetapi pada perlakuan kombinasi GA dan lama perendaman $A_{1} L_{3}$ dan $A_{4} L_{3}$ terjadi penurunan. $\mathrm{Hal}$ ini disebabkan karena beberapa faktor yang mempengaruhi diantaranya persediaan makanan dalam biji dan pengaruh dari pemberian konsentrasi yang terlalu sedikit ataupun berlebihan, dan lama perendaman yang terlalu lama. Menurut Ashari (1995:25) bahwa bila cadangan makanan tersedia dalam jumlah sedikit maka pertumbuhan tanaman akan lemah. Disamping itu, semakin lama biji 
direndam juga tidak lagi menaikan kemampuan perkecambahan benih.Biji yang terlalu lama direndam akan mengakibatkan kurangnya $\mathrm{O}_{2}$ yang menyebabkan biji tersebut sulit untuk berkecambah. Hal ini di dukung dengan pendapat Sutopo (1993) bahwa umumnya proses perkecambahan dapat terhambat bila penggunaan oksigen terhambat.

Hasil pengamatan panjang akar diperoleh nilai tertinggi pada perlakuan kombinasi GA dan lama perendaman $A_{3} L_{2}$, yaitu konsentrasi 15 ppm selama 12 jam, sedangkan hasil analisis variansinya menunjukan adanya pengaruh nyata perlakuan GA dan lama perendaman terhadap panjang akar. Ini menunjukan bahwa GA memacu panjang akar kecambah tanaman sirsak.

Proses penyerapanair pada biji sirsak berbeda dengan biji-biji pada spesies yang lain. Ini disebabkan karena struktur kulit biji sirsak berbeda dari struktur kulit biji spesies yang lain. Kulit biji sirsak memiliki struktur kulit biji yang keras sehingga untuk melunakan kulit biji selama berimbibisi diperlukan pemberian zat tumbuh giberelin yang sesuai, sehingga biji sirsak dapat berimbibisi dengan baik dan memiliki daya tumbuh kecambah yang kuat (Anonim, 2007). Sutopo (2002) yang menyatakan bahwa perlakuan benih yang mempunyai kulit keras dengan cara perendaman bahan kimia diantaranya $\mathrm{KNO}_{3}, \mathrm{H}_{2} \mathrm{SO}_{4}$, dan giberelin dapat melunakan kulit benih sehingga mempermudah masuknya air dan $\mathrm{O}_{2}$ yang dibutuhkan untuk proses perkecambahan.

Dari data pengamatan terhadap persentase perkecambahan diperoleh bahwa pada perlakuan kombinasi $G A$ dan lama perendaman $A_{1} L_{1}, A_{1} L_{2}, A_{2} L_{1}, A_{2} L_{2}, A_{2} L_{3}$, $A_{3} L_{1}, A_{3} L_{2}, A_{3} L_{3}, A_{4} L_{1}, A_{4} L_{2}$, memiliki nilai persentase perkecambahan lebih tinggi, tetapi pada perlakuan kombinasi GA dan lama perendaman $A_{1} L_{3}$ dan $A_{4} L_{3}$ terjadi penurunan. Hal ini disebabkan karena beberapa faktor yang mempengaruhi diantaranya persediaan makanan dalam biji dan pengaruh dari pemberian konsentrasi yang terlalu sedikit ataupun berlebihan, dan lama perendaman yang terlalu lama. Abidin (1993:47) yang menyatakan bahwa pertumbuhan embrio selama perkecambahan bergantung pada persiapan bahan makanan yang berada di dalam endosperm, sehingga untuk memenuhi keperluan kelangsungan hidup embrio ini, maka terjadilah penguraian secara enzimatik yaitu terjadi perubahan pati menjadi gula yang selanjutnya ditranslokasikan ke embrio sebagai sumber energi sehingga biji berkecambah. Disamping itu, semakin lama biji direndam juga tidak lagi menaikan kemampuan perkecambahan benih. Menurut Copeland (1976) dalam Abidin (1993), mengemukakan bahwa ketika proses imbibisi berlangsung maka air akan masuk kedalam biji melalui kulit biji, kemudian mengalami difusi dan masuk kedalam jaringan. Dengan masuknya air kedalam biji maka sel akan menjadi bengkak dan menyebabkan pecahnya dormansi. Selama pecahnya dormansi, aktivitas sel akan tetap berlangsung tetapi aktivitas ini membutuhkan $\mathrm{O}_{2}$. Biji yang terlalu lama direndam akan mengakibatkan kurangnya $\mathrm{O}_{2}$ yang menyebabkan biji tersebut sulit untuk berkecambah. Hal ini di dukung dengan pendapat Sutopo (2002) bahwa umumnya proses perkecambahan dapat terhambat bila penggunaan oksigen terhambat.

Hasil pengamatan perlakuan kombinasi konsentrasi GA dan lama perendaman terhadap pertumbuhan tinggi kecambah biji sirsak menunjukan bahwa nilai tertinggi diperoleh pada perlakuan kombinasi $A_{3} L_{2}$ yaitu konsentasi 15 ppm selama 12 jam, sedangkan hasil analisis variansinya menunjukan adanya pengaruh sangat nyata perlakuan GA dan lama perendaman terhadap tinggi kecambah. Ini menunjukan bahwa GA memacu bertambahnya tinggi kecambah pada tanaman sirsak. Menurut Salisbury dan Ross (1995) bahwa peningkatan panjang batang adalah respon yang paling spesifik dari kebanyakan tanaman yang diberikan giberelin, yang disebabkan karena terjadinya peningkatan aktifitas pembelahan sel dan perpanjangan sel sehingga ukuran jaringan tanaman bertambah.

Hasil pengamatan panjang akar diperoleh nilai tertinggi pada perlakuan kombinasi $G A$ dan lama perendaman $A_{3} L_{2}$, yaitu konsentrasi 15 ppm selama 12 jam, sedangkan hasil analisis variansinya menunjukan adanya pengaruh sangat nyata perlakuan GA dan lama perendaman 
terhadap panjang akar. Ini menunjukan bahwa GA memacu panjang akar kecambah tanaman sirsak. Menurut Salisbury dan Ross (1995) bahwa giberelin tidak hanya memacu perpanjangan batang tetapi juga pertumbuhan seluruh bagian tumbuhan termasuk daun dan akar. Selain itu giberelin akan merangsang sintesis auksin yang sangat dibutuhkan untuk pertumbuhan akar.

\section{KESIMPULAN}

Berdasarkan hasil penelitian yang diperoleh maka dapat disimpulkan bahwa Penggunaan konsentrasi GA dan lama perendaman yang berbeda terhadap biji sirsak memberikan pengaruh yang nyata terhadap persentase perkecambahan, tinggi kecambah, dan panjang akar kecambah. Perkecambahan biji sirsak tertinggi diperoleh pada kombinasi perlakuan $A_{3} L_{2}$ dengan nilai berturut-turut yaitu persentase perkecambahan $100 \%$, tinggi kecambah $16,12 \mathrm{~cm}$, dan panjang akar kecambah $12,99 \mathrm{~cm}$; sedangkan nilai terendah diperoleh pada kontrol dengan nilai rata-rata yaitu persentase perkecambahan 46,67\%, tinggi kecambah $5,11 \mathrm{~cm}$, dan panjang akar kecambah 4,25 cm. Disarankan Masyarakat agar sebelum menanam biji sirsak pada lahan pertanian dianjurkan untuk melakukan perendaman dalam larutan GA dengan konsentrasi 15 ppm selama 12 jam.

\section{DAFTAR PUSTAKA}

Abidin, Z. 1993. Dasar-Dasar Pengetahuan Tentang Zat Pengatur Tumbuh. Angkasa Bandung: Jakarta.

Anonim, 2007. Kunci Sukses Memperbanyak Tanaman. Agromedia Pustaka: Jakarta. Cet. Ke-3 2008.

Anonim, 2007. (Online),http://www.ibu jempol.com/manfaat-buah-sirsaksirsak-sebagai-obat-kanker-dll/. Diakses 9 Oktober 2010.

Anonim, 2010. (Online), http://isroi.wordpress.com/201 0/08/05/tanaman-pestisida- nabatisirsak-annona-muricata-l/. Diakses 9 Oktober 2010.

Anonim, 2010 (Online),http://www.planthormones.info/, Wikipedia, dll. Diakses 5 Desember 2010.
Ashari, S. 1995. Hortikultur. UI-Press: Jakarta.

Astutik., dan Puji, Y. 2006. Pengaruh Zat Pengatur Tumbuh Giberelin Terhadap Perkecambahan Biji Jati. Universitas Airlangga.

Campbell, A. N., Reace, B. J. dan Mitchel, G. K., 2003. Biologi. Erlangga : Jakarta.

Franklin, P. 1985. Fisiologi Tanaman Budidaya. Universitas Indonesia. Jakarta.

Gardner, F. P., Pearce, R. B., dan Mitchell, R. L. 1991. Fisiologi Tanaman Budidaya. Universitas Indonesia (UIPress) : Jakarta.

Gomez, A. A., dan Gomez, K. A. 1995. Prosedur Statistik Untuk Penelitian Pertanian. Universitas Indonesia (UIPress) : Jakarta.

Heddy, S. 1996. Hormon Tumbuhan. Raja Grafindo Persada: Jakarta.

Keenan, Kleinfelter dan Wood, 1999. Kimia Untuk Universitas. Erlangga: Jakarta.

Lakitan, B. 2000. Dasar-Dasar Fisiologis Tumbuhan. Raja Grafindo Persada: Jakarta.

Mayerni, R. 2007. Pengaruh Beberapa Konsentrasi Giberelin Terhadap Pertumbuhan Bibit Kina (Cinchona succirubra Pavon). Universitas Andalas Padang.

Prawiranata. 1981. Pengaruh Beberapa Bahan Kimia dan Lama Perendaman dalam Meningkatkan Perkecambahan Benih

Mucuna. (Online),http://www.scribd.com/doc/414 04743/Artikel-Mucuna. Diakses 5 Mei 2011.

Radi, J. 1997. Sirsak Budi Daya dan Pemanfaatannya. Kanisius: Yogyakarta.

Rismunandar. 1995. Hormon Tanaman. Penyebar Seri Pertanian. Jakarta.

Sallisbury dan Ross, 1995.Gibberellis (Online)http://www.adln.lib.unair.ac.id/g o.php?id=gdlhub-gdl-res-2006nfatimah-286\&PHPSESSID= $86813521 b 566 d f 5169 e 868151971 d 8 c 9$ . Diakses 9 Oktober 2010.

Soedjono dan Suskandari, 1997. Pengaruh Asam Giberelin dan Lama Perendaman Terhadap Perkecambahan Biji Palem. (Online) http:// repository. usu.ac. id/bitstream/ 
Biopendix, Volume 1, Nomor 1, Oktober 2014, hlm. 73-79

123456789/20278/4/chapter II. Diakses 2 April 2011.

Soertini dan Suskandari, 1997. Lama Waktu Perendaman.

(Online),http://digilib.umm.ac.id/go.php ?id=jiptummp-gdl-sl-2004-diyahastut91. Diakses 25 November 2010.

Sunarjono, H. 1997. Prospek Berkebun Buah. Penebar Swadaya: Jakarta.

Sutopo, L. 2002. Teknologi Benih. Raja Grafindo Persada: Jakarta.
Weaver . $1972 . \quad$ http://akmalaakmal.blogspot.com/2009/08/perananzat-pengatur-tumbuh-zpt-dalam.html. Diakses 2 April 2011.

Wilkins. 1989. Peranan Zat Pengatur Tumbuh.(Online),http://akmalaakmal.blogspot.com/2009/08/peranan-zatpengatur-tumbuh-zpt-dalam.html. Diakses 2 April 2011. 